\title{
KIND EN RELIGIE
}

'n Tematisering oor die godsdiens is net so oud soos die mens seit. As oopdekking van die verhouding mens tot God, vorm dit die tema van die gesprek tussen God en Adam na die sondeval. Sederidien was dit nog nooit afwesig in elke vorm van nalatenskap wat ons by die mens aantref nie, omdat die soeke na sinvolheid en betekenis nog altyd 'n strewe openbaar om die harmonieuse verhouding met God te herstel, al ontken die mens dit ook en al soek hy die krag van die herstel in homself. Ook die hedendaagse lewensgang is nie anders nie. Voordat die tweede dekade van hierdie eeu afgeloop was, het die groot Switserse pedagoog Foerster reeds gekla dat hoewel ons trots daarcp is dat ons meer as ooit die buitewêreld aan ons wil onderwerp het, ons opgehou het om te besef dat in werklikheid die buitewêreld meer as ooit mag gekry het oor die innerlike mens. Sy formulering was miskien minder aangrypend as die klag van Léon Bloy, wat reeds met die wenteling van die eeu uitgespreek is: God is afwesig! God is afwesig in die stede, in die velde, in die berge en op die vlakte. $\mathrm{Hy}$ is afwesig in die wet en in die wetenskap, in die politiek, in die opvoeding en in die sedes. Hy is selfs afwesig in die lewens van gelowiges, want hulle wat nog as sy vriende bekend wil staan, het geen behoefte aan sy aanwesigheid nie. God is afwesig soos nog nooit te vore nie. Afwesigheid het een van die eienskappe van God geword.

Hoe hierdie saak hom openbaar in die lewe van die moderne mens, toon Van den Berg $(19,73)$ op voortreflike wyse as hy daarop wys dat die mens God wel plaas aan die begin van die gebeure wat ons as lewe en werklikheid ken, maar dit slegs doen as 'n maatreël van veiligheid. Hy is daar, maar nie as Deelnemer nie; as Toeskouers erken die mens Hom wel, maar sluit Hom so ver moontlik uit die bedrywe uit wat ons onder sy opdrag uitvocr. As Toeskouer is $\mathrm{Hy}$ afwesig. God word in die moderne lewe 'n Banneling.

Dat die teoretisering oor die opvoeding aan hierdie houding nie ontsnap het nie, is algemeen en goed bekend. Die standpunt van bv. Rousseau benodig geen bekendstelling nie, terwyl latere godsdienspsigoloë soos Stanley Hall en Starbuck, baie jare lank die religieuse denke in die veral Anglo-Amerikaanse opvoedkundige wêreld oorheers het. Die religie, so 
beweer hulle, is wel goed umclat dit behoort tot die natuurlike aanleg van die mens. Op welke wyse hierdie naturalistiese kyk die godsulienstig-pedagogiese denke deursypel en besoedel het, is hier nie nou so direk ter sake nie. Wat egter wel ter sake is, is die pedagogiese uitspraak dat die religie weinig met die mens se aanleg te doen het, inteendeel: dit is integraal en upeisend deel van menswees. Wie opvoed of met die opvoeding bemoeid is, kan nie die religieuse gestalte van 'n kind en die ontplooiing daarvan sonder meer aan die psigologie, of nog beter aan die godsdienspsigologic oorlaat nie. Die pedagogiese kyk op sake verskil radikaal van elke vorm van psigologie om die eenvoudige rede dat die pedagogiek die norm ken, en as sodanig die godsdiens in sy normatiewe opset en normerende ingryping in die kinderlewe evalueer en bevestig, terwyl die psigologie as deskriptiewe wetenskap die norm nie kan ken nic en hom per slut van sake daaroor nie hoef uit te spreek nic. Vir die opvocder is die godsdienstige opvoeding geen beskrywing nie maar ' $n$ opgaaf omdat, soos Waterink tereg aantoon, dit gaan om die beïnvloeding en ingryping ten aansien van 'n lewenshoucling $(24,507)$. Die psigologie hou hom besig met die religie, die opvoeding met die godsdiens.

Tussen hierdie twee begrippe bestaan 'n betreklike groot verskil. Die eerste is 'n algemene verskynsel wat by en onder mense van alle tye, aard en kultuur vool kom; die godsdiens daarenteen is 'n konfessioneel gebonde leefsinhoud wat in die leefswêreld van 'n mens behoorlike gestalte moet kry. Vir die kcrk is hierdie dus 'n saak van groot betekenis. Dit is uiters belangrik dat die kerk minstens die etiese problematiek van die hedendaagse jeug reg sal verstaan. Wanneer daar hier sprake van is dat die kerk vreemd is aan 'n kind se leefswêreld, skiet hy net so tekort as wanneer hy bv. prinsipieel nie-verantwoordbare uitsprake sou gee. Die kerk moet oplaas immers ook in die kategese weet om daadwerklik pedagogies met sy niemondige lidmate om te gaan, veral in die lig daarvan dat hy in die opdrag van Matth. $28: 18$ sy doelstelling geïntendeerd afspits tot die spesifieke in teenstelling met bv. die skool se standpunt wat die meer algemene of breë vorming beoog.

Wanneer die mens dan mens, d.w.s. skepsel van God is, is die godsdienstige opvoeding geen moralisering nie, en toon dit geen verband met die euwel van die moralisme nie. Die religieuse hef die mens uit die alledaagse saaklikheid op, en 
berei 'n volkome ruspunt vir die sedelike gewete wat angedui kan word deur vernuwing, in algemeen teologiese sin. Die godsdienstige opvoeding wat ten aansien van hierdie algemene tendens moet ingryp, omsluit dan nie net alle vorme van opvoeding soos Waterink aandui nie. Alle opvoeding waarby die godsdiens betrek is, oorskry die algemene vorming in die belangrike opsig dat die waardevoorkeure nie slegs 'n algemeen sedelike karakter openbaar nie, maar 'n spesifieke belydenis met hom meedra wat 'n besondere interpretasie van die normatiewe tot gevolg het. Die interpretasie benodig ipso facto ' $n$ interpretant: ouer of kategeet wat die slingerwydte van die inhoude op spesifiek godsdienstige terrein kan skat en die gang van die beïnvloeding daarvolgens kan beplan. Belangrike pedagogiese implikasies en probleme hiervan is lankal reeds deur Bavinck aangetoon $(3,137)$ toe hy daarop geuys het dat alle religie altyd iets deur en deur persoonliks is, 'n saak van die individuele mens, en daarom eindeloos verskillend en nie so onder algemene definisies saam te vat as wat die godsdienspsigologie graag sou wou doen nie. En in die lig van moderne denke het die probleem van 'n pastorale pedagogiek dringend geword, soos Van den Berg ook tereg aantoon (20, 63 ) en verdien dit die noulettende aandag van almal wat met die kategese gemoeid is.

Om die probleme van die hedendaagse pedagogiek in hierdie opsig te begryp, moet veral twee sake deeglik voor die oë gehou word.

(a) Die lewe van 'n kind is geen gelyke gedying, 'n rustig vloeiende aangeleentheid wat eenvoudig en maklik begrypbaar van dag tot dag en fase tot fase gaan nie, maar 'n reeks van onderbrekings, soos 'n reis in die vreemde. Die lewe van 'n kind is onophoudelik oorspronklik nuut. Hierdie "nuwe" is die pedagogiese opgaaf. Die pedagoog moet dit sover moontlik antisipeer en sy opgawes en antwoorde gereed hê as hy ook aanspraak wil maak op die betiteling van opvoeder.

(b) Niks in die wêreld het 'n minder bio-meganiese verloop as die grootword van 'n kind nie. Wat bio-meganies gegee is, moet deur die kind verwerk word tot deel van sy lewensgang, waarmee ook 'n kind ophou om 'n bio-meganiese verskynsel te wees. Hierin lê die ingrypende en hulp- 
verlende mag van die opvoeding. Die "natuurlike" met betrekking tot die mens, word in hierdie bemoeienis totaal oorskry in die eksistensiële. Dit is daarom te begrype dat in die relasie kind-wêreld ook ingebou en vervleg word die singewende momente van 'n relasie mens-medemens en mens-God.

In die verhouding ten opsigte van die wêreld wat ons by 'n kind aantref, bestaan daar belangrike verskille of onderskeidinge wanneer dié van 'n volwassene (wat tog die pedagogiese mikpunt is) daarmee vergelyk word. Sonder om te diep hierop in te gaan word slegs op enkeles gewys. Die kind se wêreld is in 'n groot mate een van verpligtingloosheid, van snelle verwisseling van die appèl van die werklikheid, van 'n terloopse formalisering en van 'n oorheersing van affektiwiteit, algar faktore wat in die wêreld van 'n grootmens nie geduld word nie. Dit is daarom te begrype dat ' $n$ kind nie net oor die algemeen anders konstitueer ten aansien van die werklikheid nie, maar ook spesifiek in die godsdiens op 'n ander wyse ontwerp as wat 'n grootmens dit dikwels sou verwag. Omdat hy nog nie tot werklike distansiëring gekom het soos die grootmens nie, is sy godsdienstige houding so nou verweef met sy hele persoonlikheid dat dit hom op elke ander terrein van die lewe openbaar. Dit is daarom ook te begrype dat in die voor-puberteit die religieuse gestalte middelbaar en outoritêr bepaal word en dat ordeninge plaasvind op grond van die opvoedingsklimaat en die opvoedingspraktyk. Die aanvanklike ontwerpe van 'n kind is daarom ten nouste verweef met die wêreld wat hom onmiddellik omring en veral die wêreld waarin hy hom veilig voel. Hy ontdek derhalwe die diensaan-God aan die hand van diegene wat hom op sy lewensweg vergesel. En al is die religieuse wesenlik eie aan ' $n$ mens, wag dit op die opvoeding om dit te laat gedy tot godsdiens. Anders gesien, word dit aan die toeval oorgelaat en kan ons moontlik 'n toevallige religieuse gestalte kry. So stap 'n kind dus die wêreld as opgaaf tegemoet en ken hy betekenisse toe omdat hy daartoe gedwing word deur 'n wêreld wat sowel ordelik as genormeerd is. Sy belangrikste opgaaf of strewe is om self iemand te wees, om self groot te wees - ook in godsdienstige opsig. In die gang van hierdie gebeure sal hy wel hulp ontvang van die volwassene, maar hierdie hulp is onvol- 
ledig. Die voltooiingskarakter daarvan lê in die singewende arbeid wat die kind self sal moet verrig. Wanneer 'n kind, soos soms gebeur, aan homself oorgelaat word, kom hy te staan voor stukke onontdekte land, wat in die puberteit Niemandsland word, 'n neutrale strook waarin hy hom, veral ten op. sigte van die godsdiens, nie maklik waag nie.

Die strewe van ' $n$ kind om self iemand te wees en self groot te wees openbaar hom op verskillende wyses, wat oor die algemeen goed bekend is. 'n Belangrike wyse, wat ook noue verband hou met sy speelaktiwiteite, is sy grootweesfantasie. Pedagogies gesien, is hierdie ' $n$ eksentriese handeling wat 'n nuwe lewensruimte bied en wat aanvanklik geheel vry en spontaan, d.w.s. „oop” is, maar waarin hy ook heel gou rekening moet hou met die norme van die leefswêreld indien hy werklik ' $n$ fantasie-wêreld wil konstitueer wat plaasvervangend ten opsigte van die realiteit kan funksioneer. As die godsdienstige normstrukture hier uitgeskuif word, geskied dit nie sonder stryd nie, omdat 'n kind in hierdie grootwees-fantasie hom gedurig vasloop teen die godsdienstige feit van die bepaalde en afgegrensde waardevoorkeure en normgegewene wat hy moet interpreteer, al sou hy ook slegs die interpretasie van die volwassene oorneem. Sy probleem in hierdie opsig openbaar hy aan ons deur sy vrae. Soos elke grootmens, is ' $n$ kind ' $n$ vraende wese met probleme, die oorsprong waarvan ons ontdek in die wyse waarop hulle vrae stel. En omdat die godsdiens met die fantasie as sodanig niks te maak het nie en geen fantastiese nie maar reële leefsinhoud verbeeld, is dit ook objeksgebied van 'n kind se vraag in sy soeke na harmonie wanneer hy langs die weg van die fantasie tot konstituering van eie wêreld oorgaan.

Die feit dus dat ' $n$ kind vra ten opsigte daarvan, openbaar dat hy dit as onduidelik beleef in dié sin dat sy perspektief by historisiteitsverband en toekomstige gestalte onvoldoende d.w.s. onvoltooid daaruit sien. Hy neem egter hiermee ook in godsdienstige opsig geen genoeë nie en rig hom met sy hele wese op die verheldering daarvan. Hierdie verheldering is syns verheldering en dring sig veral aan die opvoeders op in al die wyse waarop ' $n$ kind sin en betekenis toeken. Die kinderlike singewing mag derhalwe nie losgemaak word van die kinderlike lewensvorm nie, soos bv. die behoefte aan veiligheid nie. Sy ingesteldheid op die werklikheid, die kennis en die wete 
(oortuiging) is gerig op sekerheid en geborgenheid. Die kind se lewensvorm is onverenigbaar en onversoenbaar met die sinlose of gevaarlike. In sy deurdenking van die probleme, in sy bedenkings oor die antwoorde van die grootmens, stig 'n kind dan vir homself wêreld - 'n eie wêreld wat ongevaarlik en toeganklik is en wat nie noodwendig deur die rasionele uitgekam is nie en daarom soms ook die volwassene uitsluit.

Om hierdie rede is die grootwees-fantasie so dikwels vir hom 'n redelike en aanvaarbare lewensvorm: enige iets kan inmers daarin gebeur sonder om die wêreldkarakter daarvan totaal te vernietig. Die naïewe samehang tussen werklikheid en fantasie en die ongevaarlike aanvaarding van alles wat sig aan hom voordoen, stel die drie algemeen bekende religieuse moontlikhede by die grootmens buite orde by ' $\mathrm{n}$ kind, nl., afwagting ter vervulling uit die onbekende, uitsigloosheid en skepsis. Dit behoort nie wesenlik tot synswyse en wêreldontwerpe van die jong kind nie. En indien dit wel teenwoordig is, bestaan daar groot rede tot kommer by die opvoeder. In sy gerigtheid om self godsdienstig grootmens te wees, openbaar 'n kind hom as moontlikheid-op-weg. Indien die wêreld van sy opvoeders so 'n veilige plek is dat hy hierdie veiligheid eventueel gewillig prysgee om self groot te word beteken dit dat hy nie bang is om groot te word nie.

Die jong kind stig dus uit die geheel van sy ervaring verhouding tot God en die goddelike. Die kwaliteit van die religieuse klimaat waarin hy hom bevind, is by hierdie gebeure van deurslaggewende belang vir sowel die aard as die omvang van sy beslissinge. Sonder die hulp uit sy belewingswêreld, kom 'n kind nie tot die religieuse ervaring, belewing en ontmoeting nie. Hy gaan nog veral op in die religieuse werklikheid van elke dag en sy meedoen is voorwaarde vir sy ontroering ten opsigte van hierdie inhoude. Trouens, die kwessie van inhoud word dikwels deur hom gereduseer tot gebeure ter wille van die meedoen. Hoe kleurloser en onpersoonliker die geloofsmilieu, hoe makliker volg die skepsis na die vlegeljare. Vir die goeie godsdienstige vorming is 'n godsdienstig gevormde en pedagogies fyngevoelige milieu ' $n$ voorwaarde ten einde die kind se belewingsinhoude religieus te lei tot aanvaarding van Gods beskikkingsreg. Die oortuigingskrag van die milieu lê nie eerstelik in sy bevele, aandrange of wense nie, maar in die allereenvoudigste getuienisse waardeur 'n kind die realiteit 
van die geloofshouding ervaar en as lewenshouding vir homself toeëien.

Kortweg gee Langeveld $(14,15)$ die volgende samevatting van die rol van die godsdienstige milieu ten aansien van die vorming van die kind:

1. 'n Anti-godsdienstige milieu wat sy afkeer met 'n lepel vir die kind ingee, het tot gevolg dat die haat wat eie daaraan is deur die kind oorgeneem word.

2. Wanneer die milieu onverskillig en sonder intensiewe godsdienstige kontak is, kry ons 'n totale vreemdheid, 'n utilistiese of estetiese waardering vir die godsdiens wat hom veral openbaar in ' $n$ afkeer aan die kerk.

3. Wanneer die milieu onverskillig is maar wel die godsdienstige kontak nuttig vind, kry ons die vergaande vreemdheid met ' $n$ moontlike uitwendige verkerkliking in die latere volwassenheid.

4. Wanneer die milieu kerklike tradisies wel handhaaf sonder innerlike oortuiging, kry ons die tradisionele kerklikheid met min kritiek, 'n ,toevallige" godsdienstigheid wat dikwels meer eie is aan die heidendom as aan die Christendom.

5. Sou die milieu weinig kerklike tradisie handhaaf maar tog innerlik bewoë en soekend die kind beïnvloed, vind ons gewoonlik die gebrekkige vormgewing met weinig leiding gedurende die kritiese na-puberteit wat wel daartoe voer dat die lewenshouding profiteer van die godsdienstige waardebesef.

6. Sou die milieu 'n lewende tradisie handhaaf en dus self godsdienstig lewend vertoon, vind ons 'n vrugbare pedagogiese grond en 'n goeie klimaat vir die opvoeding mits die taktvolle hantering, versigtige aanbieding en stewige vormgewing aan die orde tree.

Die variante en moontlikhede wat hierbo genoem word, beklemtoon seker in die eerste plek die afnemende sosiale betekenis van die kerk, maar lê andersyds aan die kerklike deur ' $n$ las waarvan hy hom in die huidige gou moet vergewis indien hy wil red wat daar te red is.

Voor die twaalfde lewensjaar merk mens slegs terloops hierdie tekorte in die godsdienstige vorming op, veral by die kategese. Die religieuse besef is by die jong kind eintlik geen 
probleem nie, omdat vorm en inhoud by die godsdienstige ontplooiing van die eerste jare ewewigtig geassimileer word. Hierop volg egter 'n tydvak van problematisering waarin die eindvrae, die uiteindelik fundamentele voor hom ronddobber. Sy aanvanklike oopheid teenoor wêreld en lewe blokkeer die aktualisering tot "geslotenheid". Hierdie geslotenheid is eie aan die singewing en loop eintlik hand aan hand daarmee. Vir die godsdienstige ontvouing is dit 'n baie belangrike saak, en word dit in die godsdienstige opvoeding geantisipeer. Wiat egter van nog groter betekenis in hierdie voor-puberteitsperiode is, is dat, hoe naïef die kinderlike opvattings ook mag wees, daar geen twyfel oor kan bestaan dat 'n kind die godsdienstige inhoude en belewinge intensief integreer by al die ander aspekte van sy leefswêreld nie. Daarnaas ook dat die godsdiens, by die noukeurige waarneming, vir ' $n$ kind veel meer is as vorm. Dit is 'n lewenstyl, omdat dit by die grootmens na 'n anders word heenwys onder die besieling en verinnerliking wat altyd met die godsdienstige veroweringe meegaan.

Ter samevatting kan die volgende as kenmerk van die godsdienstige lewe van die vroeë kinderjare beskou word. Hiermee word nie bedoel dat ons 'n gebeure tot ,iets" kan reduseer en dit in kompartemente kan afsonder nie, dat 'n kind na ongeveer die twaalfde lewensjaar geen van hierdie aspekte in sy lewenstyl sal vertoon nie, maar wel dat dit oor die algemeen eie is aan die godsdienstige beleuing en daarom betekenisvol is vir die vorming waarop die grootmens hom toespits $(17,295)$.

1. 'n Egosentriese ingesteldheid: wat die kind sien, sien hy as voortkomende uit die eie klein $e k$.

2. Die godsdienstige voorstellings is antropomorf van aard, en veral 'n kind se vader neem hier 'n belangrike aandeel as hy 'n sterk identifikasie-figuur is.

3. Die magiese is buitengewoon prominent en vorm vir die opvoeder dikwels 'n groot probleem.

4. Die kind openbaar 'n neweskikkende implementering van 'n primitiewe moraal wat uit die geloofslewe standpunte begin meebring oor sake soos die goeie, die liefde, die geregtigheid, vergelding en straf.

Hierby bly die kinderlike religiositeit egter nie. Die spontane uitreik na die leefswerklikheid van die grootmens word al hoe meer geïntendeerde akt wat aan die opvoedingsmilieu 
en opvoeders nuwe opgawes en probleme stel. Die kind ontdek naamlik dat hy in die godsdienstige lewe te doen het met sinservaring en singewing van absolute aard wat die ganse struktuur van die subjektiewe lewe en die wêreldordening op die vlak van die hoogste waardes belig en opeis. Hierdie verandering tree veral na vore op grond van drie belangrike aspekte van die kinderlike ontvouing.

1. Die Godsbegrip wat by die kind vorm aanneem en gestadig oorgaan tot 'n verhouding met God.

2. Die kennisgestalte wat 'n kind opbou.

3. Die besef van sonde en ellende wat by hom posvat.

Wat die Godsbegrip betref, moet begryp word dat hierdie aspek van 'n kind se begrips- en voorstellingslewe nie maklik af te grens is nie. Dit is immers in 'n hoë mate afhanklik van konvensionele invloede en lê so ver buite die mens se voorstellingswêreld dat selfs die rykste fantasering by ' $n$ kind dit nie kan omvat nie, behalwe in heel naïewe vorm. Geen kind kan per slot van sake die Godheid indink in die orde van mense nie. Hoewel God dan deur die klein kind aanvaar word as almagtig, alomteenwoordig en goed, het hy daarmee nog nie 'n greep op die bonatuurlike, die gans andere karakter van die godsdienstige wêreld nie. Wat egter wel gebeur, is dat die kind deelneem aan 'n religieuse lewe op 'n eie, unieke wyse wat hy ook in sy speelwêreld betrek in verskillende variante wat van betekenis is. Hiermee koppel hy bv. die begrafnisspeel konkreet aan sy lewensfeer vas en integreer dit deur die magiese leefshouding tot 'n algemeen aanvaarbare gestalte, en antwoord 'n sewejarige op die vraag wat dit beteken dat God eintlik Gees is, dat Hy ' $\mathrm{n}$ mens is wat onsigbaar is. Sy verhouding tot die Godheid is tydens die voor-puberteitsjare dan ook uitermate persoonlik, soos sy verhouding teenoor mense. Hierdie kwessie van die Godsbegrip is vir die opvoeder van buitengewone belang, en hy arbei daaraan met toegewydheid as hy werklik steun wil gee aan 'n kind wat volwasse moet word. Indien hy as volwassene hom op terloopse wyse hiermee bemoei, sal hy later ontdek dat die kind in die na-puberteit God op dieselfde wyse "ontmasker" het as Sinterklaas en die ooievaar.

'n Kind bou egter ook in toenemende mate 'n kennisstruktuur op. Daar is reeds op gewys dat die godsdienstige lewe 
van 'n kind aangeleentheid van die norme is, en nie bloot langs beskrywende weg afgehandel kan word nie, omdat dit intensiewe singewing meebring en as sodanig oorskryding en afronding van die Dasein-samehang beteken. Die kennisaspek is hiermee ten nouste vervleg. „To know something”, sê Erwin Straus $(18,365)$,means to determine the factual in relation to the potential, the particular in relation to the general, the part in relation to the whole. A knowing being is one no longer bound by acuality. To know what something is implies realizing what it could be but is not. To know the world implies knowledge of oneself ... The Bible tells us in a lapidary style that knowledge (scientia) is accompanied by ... conscience". Die ,anders" word van 'n kind in die puberteit in godsdienstige opsig, toon 'n besondere samehang met die ontwikkeling en toename van die kennisstruktuur. Om hierdie rede onderskei Welten byvoorbeeld in sy ondersoek na die godsdienstige belewenisse van 'n groep hoërskoolseuns uit die hoogste skoolklasse tussen godsdiens en geloof. Hy trek die onderskeid naamlik so dat met die godsdiens die akt van die godsdienstige mens ter sprake kom, teruyl by die geloof die persoonlike ingesteldheid van die individuele persoon voorop staan, d.w.s. die aktualisering van die godsdienstige inhoud $(22,224)$ binne die leefswêreld.

Nou is dit wel so dat alle religieuse wasdom staan onder die beslissings en die begeleidende geestelikheid van die wêreld waarin 'n kind groot word. Maar, dit geld ewe-eens dat geen mens hom kan losdink van byvoorbeeld sy erfenis nie en dat geen kind hom kan losmaak van die interpretasies daarvan soos dit wel deur volwassenes deurgegee word nie. $\mathrm{Om}$ in die Weste die wese van die religie te begryp beteken om dit te begryp in die lig van die Christendom. Wesenlik is hierdie begryping dan sowel belewing as kultuurvorm, en daarom in die kennend-onderskeidende omgang van die kind met die dinge in die wêreld en lewe van ingrypende betekenis. Die kenmerk van die kennende uitgaan op die geloofslewe lê dan in die spanning wat dit meebring. Ook dit is goed te verstaan as ons insien dat die spanning kenmerk van die geloof self word in hierdie jare wanneer die geloof tot 'n intensionele akt ontvou word wat voortvloei uit die feit dat mens in sy verskyningsvorm "oop" staan vir die Transendente. Die spanning in die geestesstruktuur bou dus op tussen 
geloof en verklaring. Daar is sprake van verdagtheid ten opsigte van die inhoud wat nou graag vergelyk word met die sogenaamde waterdigte teorieë van die empiriese wetenskappe. Daar is belewingskonflikte en twyfel wat hom nie net openbaar in die verhouding kind-God nie, maar ook in die verhouding kind-opvoeder. In die ontvouing van die kennisstruktuur is dit daarom belangrik dat ' $n$ kind saam met sy opvoeders ontdek dat die intellek wel vormend funksioneer by die godsdienstige veroweringe, maar dat dit self nie die diepste gemoedsbelewing tot stand kan bring wat die inhoud vorm waaroor per slot van sake nagedink word nie. Twyfel aan die vorm en uitdrukking van die eie ontmoeting met God is iets anders as twyfel aan die realiteitskarakter van die Godheid. Die grootmens moet seker, wanneer hy hierdie dinge sien gebeur, ook stil staan om homself af te vra op welke wyse sy dikwels skolastiese benadering van religieuse inhoud en Skrifopenbaring die onbewoë en lewensvreemde isolering van hierdie inhoude tot gevolg het. In welke mate lei sy eie intellektualisering tot alkeer by 'n kind omdat die gloed van die geloof in damp opgaan wanneer kilheid die kenmerk van ons eie omgaan met openbaringsinhoud geword het? En hoe sal ons hom wat affektief op die lewe uitgaan hierin mislei? Die kwessie van die kennis is tog voor alles kwessie van die bewussyn en kom veral tot openbaring as wyse van syn in die derde aspek wat hierbo genoem is, nl., die sondebewussyn, wat ' $\mathrm{n}$ ingrypende laktor is by die godsdienstige wording van 'n kind.

Die kennis van 'n kind akkumuleer in godsdienstige opsig eventueel in die hoogste mate tot die kennis van die sonde. Om die eie sonde te ken beteken ook vir 'n kind nie in die eerste plek om te weet dat hy iets verkeerd gedoen het nie, of om 'n skuldgevoel daarop na te hou ten opsigte van 'n besondere gebeurtenis nie. Dit gaan hier veel eerder om die besef van die eie feilbaarheid as feilbaarheid van die mens voor $\operatorname{God}(16,30)$. Bohne $(5,37)$ wys daarop dat die woord "sonde" nie dui op 'n menslike eienskap of op 'n tekort in die wese van die geskape mens nie, maar eerder op 'n skuldbelaaide storing van die oorspronklike verhouding tot God waardeur, die sonde in ag geneem, die regstreekse binding met die Oorsprong van ons lewe geskend is. Dit is dus 'n toestand wat hom openbaar in wat die mens doen. Indien ons 
vir die gang van die betoog hierdie twee stellings met betrekking tot die sonde sou aanvaar, is dit te begrype dat dit heelwat ryping by 'n kind kos om 'n houvas op die smartlike werk likheid van die sonde te verkry. Hy ervaar veelal die angs vir die oordeei naas cie vrees vir die straf en verwar hierdie twee belangrike fasetie van die alledaagse lewensgang in juridiese sin met sonde, skuld en oordeel in godsdienstige betekenis. By die godsdienstige vorming is hierdie saak van die uiterste betekenis vir die opvoeding, omdat die sondebewussyn, die skulubesef, die kontlik en die angs saamgroei in 'n oriëntasieprobleem t.o.v. die verhouding kind-God wat van vernietigende aurd kan wees. Die sondebesef openbaar hom in elkeen van hierdie strukture op 'n besondere wyse omdat die kind al hoe meer tyd-bewus word na mate hy ouer word, en hom derhalwe al hoe intensiewer oriënteer ten opsigte van tyd en ruimte. Die onherhaalbaarheid van die tydsverloop word nouliks elders so aangrypend ondervind as by die skuldgevoel. Skuld by 'n kind hang saam met „behoort" en "behoorlikheid", wat pedagogies belangrike sake is en dui op dit waartoe ' $n$ mens van binne uit verplig was maar wat nie tot vervulling gekom het nie. Dit wys na die krenking van 'n orde wat nie 'n menslike oursprong het nie, maar wat met die wêreldgrond geheg is. Skuld is vir hulle 'n opgawe waaraan nie voldoen is nie, en wreek hom op die innerlike deur wanorde en verwarring, omdat dit so maklik buite verhouding met berou en vergiffenis gesien word. Hiermee word die skuldbesef by 'n kind noodwendig grondvorm van menslike lewe wat hom eventueel sal openbaar in 'n lewe van dankbaarheid waaraan die pubesent later bewustelik begin deelneem. Daar bestaan egter ook begryplik 'n noue verbondenheid tussen 'n kind se skuldgevoel en sy onvermoë om behoorlik tussen goed en kwaad te onderskei. Hierdie onvermoë is geen onvermoë in sigself nie, maar wel 'n onvermoë tot beslissing wat die jong mens so gedurig verteer. Die aktualisering van hierdie skuldgevoel openbaar hom dan ook die beste in sy sporadiese berou wat hy dikwels in sy jeugdige trots verinnerlik en vir homself hou in die vrees dat hy sy nuut verworwe selfstandigheid by die betoning daarvan sal prysgee. Andersyds is die nawerking ook op te merk by die angs. Skuld en angs is belangrike en dikwels belemmerende faktore by die godsdienstige opvoeding. Die mens ontwerp in die godsdienstige lewe immers aan die hand van maar 
ook in die lig van die feit dat hy gefaal het en sal faal om aan sy opdrag gestalte te gee. Die skuldgevoel dra dan dikwels die spankrag van die godsdienstige handeling en dien as konstituerende faktor, sy dit positief of negatief. Wanneer dit egter oorslaan in angs, merk ons dat hierdie angs by 'n kind 'n aanwysing is dat hy in godsdienstige sin as mens op een of ander wyse tereg gekom het by die intuimeling van die vir hom veilige wêreld waardeur hy minder tuis in die wêreld word en waardeur sy wêreld die rug op hom keer. Die religieuse opvoeding is by hierdie gebeure daarop ingestel om die angs te oorwin in belydenis. Die opvoeder soek hier geen brullende vrees by die jongmens nie en koester eerder die kind in die warme geloofsekerheid dat Christus self alles oorwin het. Angs is per slot van sake 'n toestand wat eie aan die mens en onskadelik is wanneer so 'n kind oor die angs heen die vrymakende verlossing kan sien as sy eiendom. So 'n angs is iets heeltemal anders as 'n religieuse trauma of histerie wat dikwels die nawerking van religieuse opsweping is. Die kind se neiging om te vrees binne die raamwerk en vertroebeling van die skuldgevoel as uitingsvorm van die sondebewussyn skep derhalwe dikwels vir die opvoeding besondere probleme. 'n Belangrike aspek is die kind se geneigdheid tot 'n magiese interpretasie van inhoude, wat in sy vernietigende werking direk afstoot op die konflik. Hierdie neiging by kinders toon hom gewoonlik as 'n omkoop van die wêreld en is vir die opvoeder wat struktuur wil help bou in die verantwoordelikheid, nie aanvaarbaar nie. Die volwassene bestry dit om die kind te help losmaak van sy naïef-realistiese wêreldbeeld, nie langs die weg van die primitiewe selfbeskerming nie, maar wel deur die oproep tot die berou. In die godsdienstige opvoeding veg mens dus teen die angs wat tot magiese interpretasies lei of wat aan die intellek 'n vernietigende rol toeken. Angs is godsdienstig-pedagogies slegs te regverdig as 'n mens besef dat hy gedurig te staan kom voor die allerheiligste majesteit van God en waar die nietigheidsbesef die dankbaarheid kan wek dat ook jy in die genade opgeneem en geborge is: nie eendag nie, maar nou. Hierdie geborgenheid kry nie slegs gestalte as besef nie, maar word daagliks gelewe. Die godsdienstigheid in sy samehang met die angs is geen ontvlugting van die werklikheid nie, maar 'n singewing daaraan en ' $n$ omstelling daarvan, anders is dit geen opvoeding nie maar 
infantilisering van lewensgebeure. Wanneer die magiese in samehang met die angs clus in die kind se gryp na die godsdiens na vore tree, breek die volwassene verskillende fasette van die kind se lewenshouding af. Die afbreek van die ingesteldheid op die magiese wat bv. so eie is an die kindergebed, is in werklikheid hulp en vormgewing. Dit is ontbinding en atstroping van die ek-bepaalde ingesteldheid wat 'n kind daartoe voer om te begryp dat sy $e k$-godsclienstigheid nie die wêreld sal maak soos hy hom wil hê nie. Die Christen-opvoeders laat geen geleentheid verbygaan om die kind tot die besef te bring dat God nie sy kneg is nie en dat Hy ewe-eens geen Sinterklaasfiguur is nie. Tegelyk moet die kind hom egter in die Godsfeer veilig voel en weet dat hy in blydskap en vertroue dit met Hom kan waag. Menige opvoeder brand dikwels van teleurstelling wanneer hy die grofste positiwisme en oppervlakkigheid, selfs platheid by die puber aantref. Ons moet egter onthou dat hierdie kind in 'n tydvak van omvangryke labiliteit verkeer, blootgestel aan die teenstrydigste invloede, selfs in 'n positiewe en homogene milieu; dat hy vorm gedurig verwar met inhoud; dat hy bid en dan diep binne in hom God voor die keuse stel om hom sy sin te gee of as non-entiteit beskou te word; dat hy na so 'n onverhoorde dwanggebed ontnugter is; dat sy utilistiese waardebepalings direk bots met 'n godsdienstig gefundeerde etiek, maar bo alles dat hy langs hierdie weg nie by God in Christus kan uitkom nie. Die onophefte angs en die onbedekte skuld bring dan die godsdienstige konflik.

Die konflik is 'n algemene verskynsel by die opvoeding en openbaar hom in verskillende pedagogiese situasies op verskillende wyses. De Klerk $(7,79)$ praat in die algemene opvoedingsgang van eksterne konflikte, d.w.s. konflikte na buite gerig en interne konflikte, d.w.s. innerlike disharmonieë. Beide hierdie vorme vind ons by die godsdienstige opvoeding. Daar ontstaan by ' $n$ kind ' $n$ vrees om met homself besig te wees, 'n wegvlug vir die selfontdekking, terwyl hierdie selfontdekking tog besliste voorwaarde vir die verdere ontdekking en ordening van die werklikheid is. Die godsdienskrisis wat hieruit voortvloei, openbaar hom dan dikwels by hierdie kinders wanneer die kinderlike verhouding tot werklike lewensituasies moet oorgaan tot volwasse relasies. Die "sintuiglik-objektiewe" skiet dan te kort in die sin van 'n ",nog nie geestelike nie"; sy vroeër harmonieuse verhouding met mense aan die hand 
waarvan soveel konstituering plaasvind, val deur as hy werklik kennis maak met die hulpeloosheid van diegene wat hy as geestelik sterk beskou het; die liefdeloosheid van diegene wat hy liefhet; die selfsug van diegene by wie hy offervaardigheid verwag het. Wanneer 'n puberteitskind dan oor die algemeen vir homself tot probleem geword het, verander sy verhouding tot die wêrelà biune die konfliksituasie soms radikaal: die wêreld word nou self probleem en hy trag om die probleem te interpreteer deur die $e k$ waardeur die geheel opgeneem moet word in sy eie, innerlike waardering van die dinge. Daardeur ontdek hy die waardes en ontdek sy opvoeders op hulle beurt die kern van die puberteitskonflik as pedagogiese probleem. Wanneer dit nou byvoorbeeld gebeur dat daar onvoldoende distansiëring by sowel opvoeder as kind in hierdie konfliksituasie is, kry dit nie die pedagogiese betekenis wat dit behoort te hê nie en ontaard dit in 'n krisis. So is ook die religieuse konfliksituasie geleentheid tot kreatiwiteit. Enersyds deur intensiewe hulpverlening en aanvaarding deur die volwassene, maar andersyds ook deur volgehoue en selfs meedoënlose waardekonfrontering wat die kind voor homself plaas sonder om hom aan homself (sy angs, sy twyfel en huiwering, sy kennisgebrek, sy beperkte ervaring, sy oppervlakkige belewinge) uit te lewer. Die konfrontasie beteken nie om kind en waarde bymekaar te bring en dan alleen te laat nie, maar wel konstruktiewe bemoeienis ter wille van die selfverwesenliking, die skepping van nuwe verhoudinge en die verwerwing van insigte wat blyke sal gee van wordende volwassenheid. Te midde van hierdie verwarrende en soms verwilderende gebeure, moet die puber nou staanplek en standpunt t.o.v. die eie geloof verwerf. En om eventueel godsdienstige wasdom te bereik lê vir 'n kind 'n omvangryke opgaaf ten laste. Dit gaan immers om die afbreek van die kinderlik-naïewe goedertrou: Moeder is goed; Vader is goed, terwyl hy nou die omvang van die stelling ontdek dat albei voor God doemwaardig is. Die godsdienstige wasdom breek eers deur wanneer die wêreld d.w.s. die gesin, die kerk, die skool nie meer vir die kind die veilige plek is wat dit eens was nie. Wat hier gebeur, is geen ontwikkeling nie, veral nie in naturalistiese sin nie. Veel eerder is dit ' $n$ toeëiening van ' $n$ werklikheid buite die kind se lewensingesteldheid. Die aandeel van die opvoeders is hier onbepaalbaar groot, só groot dat "toeval", ,natuurlikheid", 
„spontaneiteit" heeltemal vervang word met en verplaas word na 'n leefsw'êreld waarin 'n volwassene hom gryp en met die diens aan God as leefswerklikineid konfronteer op so 'n wyse dat dit oorheersend word in die eie synsvoltrekking.

Wat is egter nou die aard van hierdie opgawe om self godsdienstig groot te word? Veral dit: Dat die puberteitskind afgesien van vader, moeder of kategeet maar aan die hand van hulle steungewing 'n eie geloofsgestalte sal verwert. So 'n kind staan veel sterker as die een wat aan die kinderlikheid krampagtig vasklou en wat 'n oorrompelende krisis kan veroorsaak wanneer die vroeg-kinderlike volgsaamheid eendag moet verkrummel en hy self moet kies. Om hierdie kwessie van geloofskeuse draai die kern van die probleem as pedagogiese aangeleentheid. Om die aard hiervan te verstaan, moet die opvoeder insien dat elkeen van die vooraf genoemde aspekte, te wete skuld- en sondebewussyn, angs en konflik, by die kwessie van die keuse betrek word. Die krisis van die keuse openbaar hom nie net byvoorbeeld in 'n poging van die kant van die kind om 'n natuurkundige verklaring oor sê maar die Skrifwonders te gee nie; ook nie om in die beantwoording van probleemvrae oor sake soos hemel en hel, sonde, lewe na die dood, geloof ens. te slaag nie. Dit gaan veel eerder om 'n poging om sigself opnuut in die oorgelewerde in te leef in die sin van dit opnuut te verwerf. Fierdie is ' $n$ epoch van kritiek wat opvoeder en kind in die religieuse samesyn dikwels van mekaar losskud. So verwag kinders soms 'n opspraakwekkende gedaanteverwisseling by die eerste gebruik van die sakrament en wanneer dit uitbly, verstik hulle maklik in uiterlikhede, waardeur die ou kringloop van selfbeskuldiging, konflik en keusekrisis tot 'n dalende lyn in die geloofslewe voer. Die kritiese houding van die kind in hierdie jare, weet ons, is nie gegrond op diepgaande insigte nie. Oor die algemeen streef hulle egter na 'n eie verantwoording van die lewe en lewensbeskouing en kan dus tot die geloof kom wat hom veral openbaar in die opwellings van binne uit; ' $n$ verlange na die onvolkome en onvoorwaardelike, 'n verlange wat eintlik eie is aan die puberteit. Dit is daarom begryplik dat hy uitermate wantrouig is teenoor "godsdienstige" en "vroom" mense; hy is sporadies bereid om te luister en intens vatbaar vir die persoonlike kwaliteite van diegene wat met hom oor die geloof spreek. Hy is afkerig aan outoriteitsvertoon sonder om outoriteit te verwerp. Sleurende gebede 
en godsdiensformalisme grief hom uitermate. Sy lewe, ook op godsdienstige terrein, word 'n lewe van teëstellings. Maar in sy warse houding merk ons tog die ontvouing van 'n mens wat enersyds berus op die gryp uit sy innerlike na die godsdienstige, d.w.s. op die eenheid, die sinvolheid, geborgenheid en gerigtheid as houding teenoor dit wat die werklikheid aan hom opdring; en andersyds op die opvoeding, d.w.s. die gang van die ontvouing word geborg deur clie voorwaardes wat die opvoeding stel. Die ontvouing word as ' $t$ ware afhanklik van die aangebode voorwaardes in die opvoeding. Religieuse ontwikkeling en godsdienstige opvoeding is twee dinge: die laaste beskerm die kind teen die eerste in hierdie tydperk.

In sy bemoeiinge met hierdie saak bring die grootmens die kind dan tot die besef dat hy te staan gekom het voor 'n alles te bowe gaande dinamiek; ' $n$ besef dat ook hy opgeneem is in ' $n$ orde ten goede, 'n orde ter herstel, 'n orde van heling en beleid wat berekening, toeval en meganiese bepaaldheid oorskry en die genade ter behoud beskikbaar stel. Hierdie oorskryding van die werklikheid ervaar die pubesent dikwels as asemberowend. Sy transenderende handelinge en sy gedurige vooruitgryp na wat kan wees, stel hom voor sy tekort aan perspektief en werp hom op diegene wat sê dat hulle weet. Hy leef dikwels meer onder vermoede as in sekerhede, in verwagtings as ervarings - maar wat hy wel in groter mate beskikbaar vind, is sy oriëntasie ten opsigte van die tyd. Hiermee tree na vore die radikale transendensie van die personale sin, van syn in die wêreld. Wanneer dit belangrik word, is hy ryp vir die gryp na die heilsgedagte waardeur hierdie wêreld finaal oorwin word. Die geheimnis van „buite die tyd" word begeerlik. In die godsdiens hou mens jouself met hierdie geheim besig wat dit tegelyk sinvol en geheimnisvol maak. Die opgaan in die Onsienlike word hiermee 'n aangeleentheid van veiligheid wat kosbaar is om te besit. Die keuse vir die godsdiens is daarmee gemaak. Dit sal nog baie jare van geïntendeerde deelname kos om die ruimte wat hy ontdek het om te skep tot woonplek vir die gees, om die werklikheid bo en buite hom 'n oorkoepelende en deursurende karakter te laat kry. Maar hy is onderweg na belewing en ontmoeting wat hom tot in der ewigheid nie ongedeerd sal laat nie. So is die godsdienstige ontvouing synsbevryding deurdat dit wat is daarin oorskry word tot dit wat moet wees. Dat die kind die religieuse gaan probeer 
lasionaliseer, moet die volwassene verwag en daarop voorbereidings tref. Ons moet as grootmense egter baie goed onderskei tussen die rasionele in die godsdiens en die rasionalisme. Die werklik godsdienstige waarhede kan nie deur 'n rasionalisme gedra word nie. Sy waarheid oorskry die rede soos die wete die kennis oorskry. Daarom laat ons tereg nie 'n kind vir hornself 'n religieuse konsepsie opbou nie, hoewel ons noukeurig op die belewings- en ervaringsmoontlikhede let en daarvolgens aan 'n kind 'n stuk verantwoordelikheid vir sy wêreldbeeld toeken. Wanneer die godsdiens dan uitermate gerasionaliseer word, verskraal dit tot feite wat met mekaar noet klop en daarom onaanvaarbaar word. Sou 'n kind dan halfpad vassteek en sy godsdiens ' $n$ kwasi-intellektuele karakter kry, slaan die skepsis onmiddellik toe. 'n Kind neem net vcrantwoordelikheid in die geloof wanneer die vorming geleentheid vir die waaragtige skep wat veral openbaar in die vrome beskeidenheid van sy opvoeders eerder as in kennis.

Tot ontsnapping aan hierdie gevare moet die opvoeding die steun gee, omdat die geloofshouding die breër lewenshouding op geen wyse ongedeerd laat nie. Die fundamentele besluite ten opsigte van die godsdienstige word meteens deurgetrek na die erotiese en die algemene intellektuele ontwaking in 'n nou veel groter lewenshorison waarin die verhouding tot God die res begelei in plaas van omgekeerd. Die bekeringsbeloog van sowel Stanley Hall as Starbuck het in hierdie struktuur geen plek nie, en dit is stellig onjuis om die godsdienstige ontplooiing terug te probeer voer na 'n bekeringsmoment, omdat daar niks verhelder word ten aansien van die aanloop tot 'n keuse wat op dieper grond as emosionaliteit gemaak word nie. Waar die evidente belewing, d.w.s. die belewing van oorluigde sekerheid gevoelsmatig 'n dieptegang toon, en waar gegewens van nie-afleibare aard bewustelik aanvaar en geïntegreer word met afleibare gegewens tot 'n geheel of struktuur, kan mens sê dat 'n kind tot 'n godsdienstige gestalte gekom het. Dat die kategese hieraan 'n besondere deel neem, spreek eintlik vanself. Dit is immers ' $n$ gebeure, 'n verloop waartydens aan 'n kind iets gebied moet word om oor te dink, liewer as iets om ligvaardig te aanvaar; iets om oor te vra, liewer as iets om najef en gedagteloos oor heen te stap.

Die "nuwe" werklikheid waarvan sowel kategeet as opvoeder praat, kan as nuwe werklikheid beskryf word, nie om- 
dat dit gekoppel word aan 'n idee soos goedheid of regverdig. heid nie, maar aan 'n Persoon wat as Middelaar staan tussen die kind en sy eventuele herskepping en wat die krisis van die mense in al sy kulminasie-punte ophef. So word die onverklaarbare nie verklaar nie, maar ter syde gestel deur 'n Regter wat tegelyk Verlosser is, en is die godsdienstige opvoeding letterlik beskerming teen die vernielende mag van die intelligensie. Die opvoeder en kategeet plaas die swaartepunt van die keuse transendent buite die kind, maar wel binne sy bereik sodat die godsdienstige perspektief essensieel die werklikheid transendeer waarby die $\sin$ van die keuse oopgedek en toegeëien kan word. Hierdie singewing kry veral gestalte in die verinnerliking van die gebeure, d.w.s. deur die aanvaarding van 'n lewenshouding wat getuig van oriëntasie en perspektief op die problematiek van tyd en ewigheid.

Die religieuse mens wil daarom die religieuse opvoeding van sy kind, sê Langeveld, maar so veel te meer wil die godsdienstige mens die godsdienstige opvoeding van syne.

Pretoria.

F. van der Stoep

\section{LITERATUURLYS}

1. Aeppli, E.: Persoonlijkheid (Vert.). Erven J. Bijleveld, Utrecht 1956.

2. Ausubel, D. P.: Theory and problems of Child Development. Grune \& Stratton. New York 1958.

3. Bavinck, H.: Wijsbegeerte der Openbaring. J. H. Kok, Kampen 1908.

4. Beets, N.: Over lichaamsbeleving en sexualiteit in die puberteit. Erven J. Bijleveld, Utrecht 1958.

5. Bohne, G.: Aufgabe und Weg der Erziehung in der Verantwortung vor Gott. Im Furche-Verlag. Hamburg 1960.

6. Brillenburg Wurth, G.: Zedelijke Opvoeding. J. H. Kok, N.V., Kampen 1960.

7. De Klerk, L.: De Grondsituatie der Puberteitsopvoeding. Wolters, Groningen/Diakarta 1954.

8. Copei, F.: Der Fruchtbare Moment vir Bildingsprozess. Quell \& Meyer, Heidelberg 1963. (7e druk).

9. Flitner, Andreas. (Red.): Wege zur pädagogischen Antropologie. Quelle \& Meyer, Heidelberg 1963.

10. Foerster, F. W.: Opvoeding en zelfopvoeding. (Vert). J. Ploysma, Zeist 1917.

11. Gunning, J. H. (W.z.): Verzamelde Paedagogische Opstellen. (2e bundel). Amsterdam - S. L. van Looy 1911.

12. Hansen, W.: Die Entwichlung des Kindlichen Weltbildes. Köselverlag. Munchen 1959. (5e hersiene druk). 
13. Kohnstamm, Ph.: Persoonlijkheid in Wording. Tjeenk Willink \& Zoon, Haarlem 1929.

14. Langeveld, M. J.: Inleiding tot de studie der paedagogische psychologie van die Middelbare-Schoolleeftijd. Wolters, Groningen 1961. 7e dr.

15. Langeveld, M. J.: Beknopt Theoretische Paedagogiek. Wolters, Groningen 1952. (4e druk).

16. Langeveld, M. J.: Kind en Religie. Erven J. Bijleveld, Utrecht 1956

17. Spranger, Eduard: Psychologie des Jugendalters. Verlag Quelle \& Meyer, Leipzig. 17e druk. 1932.

18. Straus, Erwin: Psychologie der menschlichen Welt. Springer-verlag Berlin-Göttingen - Heidelberg 1960. (On the form and structure of man's inner freedom).

19. Van den Berg, J. H.: Metabletica. G. F. Callenbach, N.V., Nijkerk. (1le druk).

20. Van den Berg, J. H.: Psychologie en Geloof. G. F. Callenbach, N.V. Nijkerk 1958. 2e druk.

21. Van den Berg, J. H.: Psychologie en theologische antropologie. G. F Callenbach, N.V., Nijkerk 1963. (3e druk).

22. Welten, V. J.: Godsdienstigheid en groei naar volwassenheid, in Hoogveld Instituut: Pedagogisch Denken. J. J. Romen \& Zonen. Roermond-Maaseik 1958.

23. Waterink, J.: Puberteit. N.V. Gebr. Zomer en Keuning Uitgeversmy., Wageningen 1948 (4e druk).

24. Waterink, J.: Theorie der Opvoeding. J. H. Kok, N.V., Kampen 1951. 